\title{
Global transcription profiling reveals differential responses to chronic nitrogen stress and putative nitrogen regulatory components in Arabidopsis
}

\author{
Yong-Mei $\mathrm{Bi}^{1}$, Rong-Lin Wang${ }^{2}$, Tong $\mathrm{Zhu}^{3}$ and Steven J Rothstein*1
}

Address: ${ }^{1}$ Department of Molecular and Cellular Biology, University of Guelph, Guelph, Ontario, N1G 2W1, Canada, ${ }^{2}$ Ecological Exposure Research Division, National Exposure Research Lab, US EPA, 26 W. Martin Luther King Dr., Cincinnati, OH 45268, USA and ${ }^{3}$ Syngenta Biotechnology Inc., 3054 Cornwallis Road, Research Triangle Park, North Carolina, 27709, USA

Email: Yong-Mei Bi - ybi@uoguelph.ca; Rong-Lin Wang -Wang.Rong-Lin@epamail.epa.gov; Tong Zhu - tong.zhu@syngenta.com; Steven J Rothstein* - rothstei@uoguelph.ca

* Corresponding author

Published: 16 August 2007

BMC Genomics 2007, 8:28I doi:10.1/86/|47|-2164-8-28|
Received: 18 April 2007

Accepted: 16 August 2007

This article is available from: http://www.biomedcentral.com/I47I-2164/8/28I

(c) $2007 \mathrm{Bi}$ et al; licensee BioMed Central Ltd.

This is an Open Access article distributed under the terms of the Creative Commons Attribution License (http://creativecommons.org/licenses/by/2.0), which permits unrestricted use, distribution, and reproduction in any medium, provided the original work is properly cited.

\begin{abstract}
Background: A large quantity of nitrogen $(\mathrm{N})$ fertilizer is used for crop production to achieve high yields at a significant economic and environmental cost. Efforts have been directed to understanding the molecular basis of plant responses to $\mathrm{N}$ and identifying $\mathrm{N}$-responsive genes in order to manipulate their expression, thus enabling plants to use $\mathrm{N}$ more efficiently. No studies have yet delineated these responses at the transcriptional level when plants are grown under chronic $\mathrm{N}$ stress and the understanding of regulatory elements involved in $\mathrm{N}$ response is very limited.
\end{abstract}

Results: To further our understanding of the response of plants to varying $N$ levels, a growth system was developed where $\mathrm{N}$ was the growth-limiting factor. An Arabidopsis whole genome microarray was used to evaluate global gene expression under different $\mathrm{N}$ conditions. Differentially expressed genes under mild or severe chronic $\mathrm{N}$ stress were identified. Mild $\mathrm{N}$ stress triggered only a small set of genes significantly different at the transcriptional level, which are largely involved in various stress responses. Plant responses were much more pronounced under severe $\mathrm{N}$ stress, involving a large number of genes in many different biological processes. Differentially expressed genes were also identified in response to short- and long-term $N$ availability increases. Putative $N$ regulatory elements were determined along with several previously known motifs involved in the responses to $\mathrm{N}$ and carbon availability as well as plant stress.

Conclusion: Differentially expressed genes identified provide additional insights into the coordination of the complex $\mathrm{N}$ responses of plants and the components of the $\mathrm{N}$ response mechanism. Putative $\mathrm{N}$ regulatory elements were identified to reveal possible new components of the regulatory network for plant $\mathrm{N}$ responses. A better understanding of the complex regulatory network for plant $\mathrm{N}$ responses will help lead to strategies to improve $\mathrm{N}$ use efficiency.

\section{Background}

Nitrogen $(\mathrm{N})$ is the most important inorganic nutrient for plant growth [1]. It affects many aspects of plant growth and development, such as $\mathrm{N}$ and carbon (C) allocation, root branching, leaf growth and flowering time [2-5]. The production of high-yielding crops is associated with the 
application of a large quantity of fertilizers at a substantial cost [6], and $\mathrm{N}$ pollution is becoming a threat to global ecosystems $[7,8]$. Efforts have been directed to understanding the molecular basis of plant responses to $\mathrm{N}$ and to identifying $\mathrm{N}$-responsive genes in order to manipulate their expression and enable plants to use $\mathrm{N}$ more efficiently [9].

Nitrate is the major source of $\mathrm{N}$ in agricultural soils [10]. It serves as a nutrient and as a signal $[11,12]$. As a nutrient, it is taken up by the low and high affinity nitrate transporter gene family members (NRT1 and NRT2), reduced to nitrite by nitrate reductase (NR), and to ammonium by nitrite reductase (NiR). Ammonium is then incorporated into amino acids, catalyzed primarily by glutamine synthetase (GS) and glutamate synthase (GOGAT) [11-14]. As a signal, it can induce the expression of a number of genes including NRT1, NRT2, NR and NiR $[4,12,15,16]$. The expression of the ammonium assimilatory genes, GS and GOGAT, are also induced by the addition of nitrate $[12,13]$, as are genes involved in sugar metabolism and other metabolic pathways [17]. In addition to these metabolic genes, expression of some regulatory genes is also affected by N levels. For example, the Arabidopsis MADSbox gene ANR1, which regulates lateral root development, responds to $\mathrm{N}$, but not potassium or phosphate [3].

There have been several studies of plant $\mathrm{N}$-responses based on microarray gene expression profiling. Wang et al [18] studied the response of seedlings grown on ammonium to the addition of low or high levels of nitrate. They used the Arabidopsis GEM1 microarrays, which contained 7942 cDNA clones corresponding to 5524 unique genes, and identified 25 and $49 \mathrm{~N}$-responsive genes to low or high nitrate induction, respectively [18]. Subsequently, Wang et al [19] used the Arabidopsis whole-genome Affymetrix ATH1 microarray containing 22,626 genes, to study the addition of the low level of nitrate to discover more N-responsive genes. Scheible et al [20] also used the ATH1 microarray combined with real-time RT-PCR of $>$ 1,400 transcription factor genes to identify genes affected by $\mathrm{N}$-deprivation or $\mathrm{N}$-induction after $30 \mathrm{~min}$ or $3 \mathrm{hr}$ from $\mathrm{N}$-starved seedlings. Since $\mathrm{C}$ and $\mathrm{N}$ metabolism are very closely linked and tightly regulated [21,22], Price et al [23] used the ATH1 microarray to identify the individual contributions of nitrogen, sugar, and nitrogen plus sugar on global gene expression. Recently, Lian et al reported expression profiles of 10,422 genes at an early stage of low $\mathrm{N}$ stress in rice seedling [24].

So far, these studies have provided valuable insights into $\mathrm{N}$ response and its linkage to other biological pathways. However, no studies have yet delineated the responses at the transcriptional level when plants are grown under chronic N stress. Earlier reports involved investigations of transient changes in gene expression when nitrate is added to nitrate-starved seedlings [18-20,23]. As such, many questions still remain unanswered. For example, it is not clear how mature plants would respond to different degrees of chronic $\mathrm{N}$ stress. A growth system was developed where $\mathrm{N}$ was the growth-limiting factor, so the transcriptional changes of genes that were most affected by different degrees of $\mathrm{N}$ limitation could be investigated. Additionally, the global transient changes during $\mathrm{N}$ induction were examined by transferring mature plants from low $\mathrm{N}$ to high $\mathrm{N}$ instead of using $\mathrm{N}$-starved seedlings. In addition, putative regulatory elements involved in $\mathrm{N}$ response were also identified as an important first step toward understanding $\mathrm{N}$ regulatory networks. Previous progress in this area is limited to nitrate induction from deletion analysis of $N R$ or NiR promoters [25-29], and a study on the interaction between $\mathrm{C}$ and $\mathrm{N}$ signaling [30].

\section{Results and discussion \\ Developing defined nitrogen growth conditions for expression profiling}

To apply chronic $\mathrm{N}$ stress, it is important to develop a defined nitrogen growth condition. It is difficult to maintain a constant $\mathrm{N}$ level in a soil system due to the different size and affinity of soil particles for nutrients. A "pure" hydroponic system could control the $\mathrm{N}$ level well but the root system is not supported by a substrate and it is bathed directly in the nutrient solution with poor aeration. To overcome those shortcomings, a hydroponic system using rockwool as the growing substrate was adopted [31]. The key quality of high grade rockwool is uniform wetting. It provides a buffering reservoir of nutrient solution in the root zone, while maintaining an adequate volume of air (oxygen). A detailed description of the system is provided in the Methods section. Wild-type Arabidopsis (Columbia ecotype) plants at 3 weeks of age were evaluated for shoot biomass under different $\mathrm{N}$ conditions, ranging from $0.1 \mathrm{mM}$ to $10 \mathrm{mM}$. Under these $\mathrm{N}$ conditions, $3 \mathrm{mM}$ nitrate was found to give maximal growth (data not shown). For subsequent experiments, $3 \mathrm{mM}$ nitrate was used to produce the $\mathrm{N}$-sufficient condition, 1 $\mathrm{mM}$ nitrate to produce the mild N-limiting condition, under which plant growth measured by shoot biomass was reduced to approximately $80 \%$ of that at $3 \mathrm{mM}$ nitrate, and $0.3 \mathrm{mM}$ nitrate to produce the severe N-limiting condition, under which plant growth measured by shoot biomass was further reduced to approximately $35 \%$ of that at $3 \mathrm{mM}$ nitrate (Figure 1a). Under these conditions, the nitrate levels in the leaves ranged from $0.24 \mathrm{mg} /$ g FW to $1.64 \mathrm{mg} / \mathrm{g}$ FW (Figure 1b). Plants have a nitrate transport system that could have a very high affinity for nitrate [32] and provide a certain capacity for nitrate absorption at low external nitrate concentrations. However, in our system, the amount of nitrate in one rockwool cube that was available to support the growth of one plant 

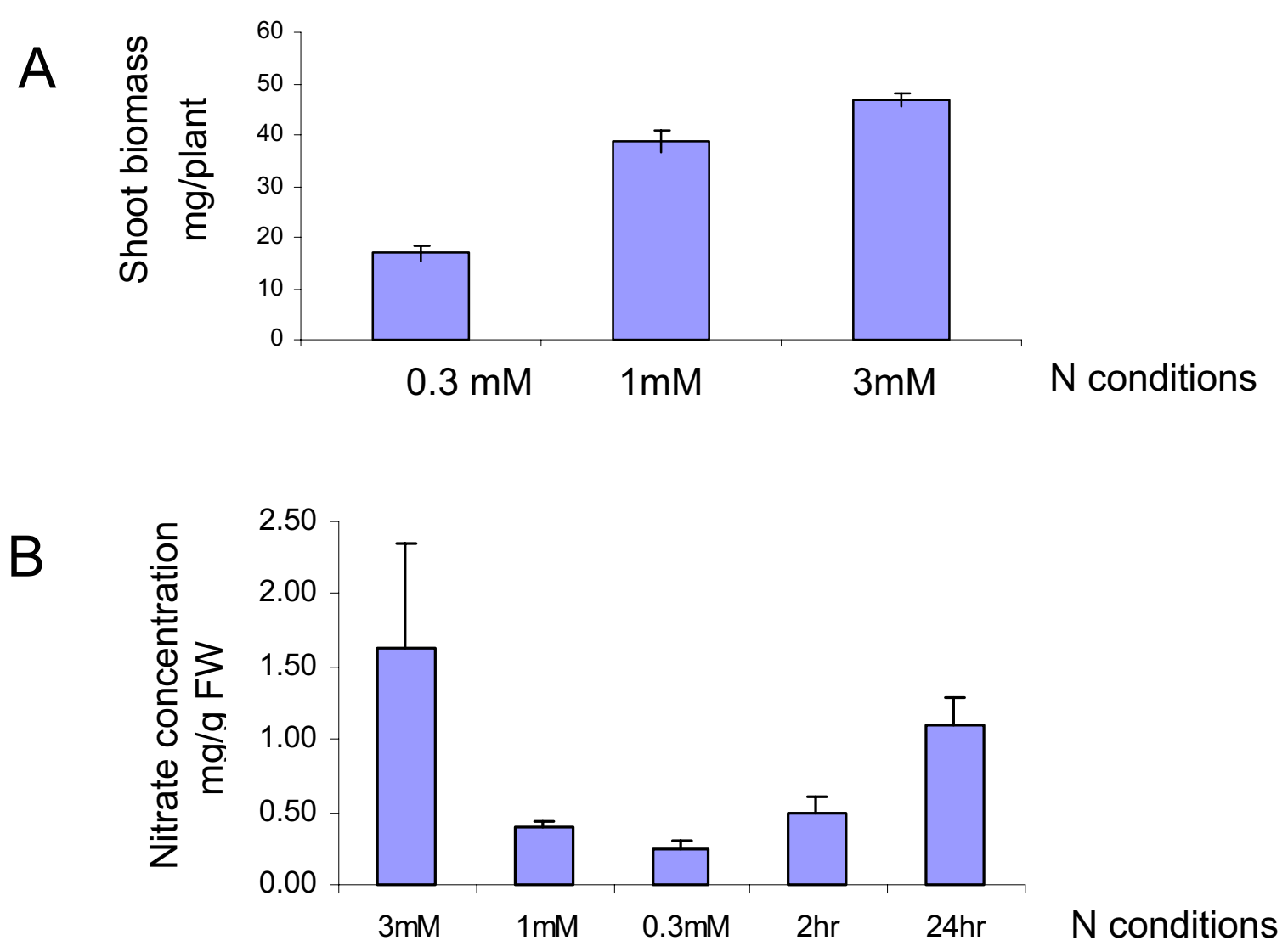

\section{Figure I}

Three-week-old wild type Arabidopsis plants under different $\mathrm{N}$ conditions. A: Shoot biomass. Average of shoot biomass (mg/ plant) of 6 to 8 three-week-old wild type Arabidopsis plants under the $\mathrm{N}$-sufficient $(3 \mathrm{mM})$, mild $(\mathrm{I} \mathrm{mM})$ and severe $(0.3 \mathrm{mM})$ $\mathrm{N}$-limiting conditions are presented, as well as sd. B: Nitrate levels: Average of nitrate levels (mg/g fresh weight) of 3 biological samples under different $\mathrm{N}$ conditions (each sample from a pool of 3 plants) are presented, as well as sd.

was apparently very limited under the low $\mathrm{N}$ conditions. The consequence was the obvious difference in growth under these $\mathrm{N}$ conditions. Apart from reduced shoot biomass due to $\mathrm{N}$ deficiency, a reduction in chlorophyll level was also observed (data not shown).

\section{Identification of differentially expressed genes by expression profiling}

Shoots of 3-week-old wild-type plants grown under the Nsufficient condition ( $3 \mathrm{mM}$ nitrate), the mild $\mathrm{N}$-limiting condition ( $1 \mathrm{mM}$ nitrate) and the severe N-limiting condition $(0.3 \mathrm{mM}$ nitrate) were harvested for the profiling experiment to compare the baseline gene expression levels under different, but stable $\mathrm{N}$ conditions. Since it is known that the expression levels of nitrate assimilation genes are high early in the day and low late in the day, all samples were taken at the middle of the day to minimize diurnal changes in $\mathrm{C}$ and $\mathrm{N}$ metabolism [33]. Each condition had three biological replicates. Also, at 2 hrs or 24 hrs before the harvest, some of the plants grown under the severe $\mathrm{N}$ limiting condition $(0.3 \mathrm{mM}$ nitrate) were transferred to the N-sufficient condition ( $3 \mathrm{mM}$ nitrate), and then collected at the same time as those grown under different stable $\mathrm{N}$ conditions to assess gene expression changes after 2 hr or $24 \mathrm{hr} \mathrm{N}$ induction. Nitrate levels in the leaves increased from $0.24 \mathrm{mg} / \mathrm{g} \mathrm{FW}$ to $0.49 \mathrm{mg} / \mathrm{g} \mathrm{FW} 2 \mathrm{hr}$ after addition of higher levels of nitrate and to $1.09 \mathrm{mg} / \mathrm{g}$ FW after $24 \mathrm{hr}$ (Figure 1b). Again, three biological repeats 
were collected for each time point. RNA was extracted and hybridized to a custom designed Arabidopsis GeneChip ${ }^{\circledast}$ whole genome microarray. This microarray contains 26,412 probe sets representing 26,367 Arabidopsis known and predicted genes. On average, each gene contains 15 perfect match probes, selected from the 3 ' end of 133,397 exons [34].

Significance analysis of microarray (SAM; academic version 2.23B) [35] was used to identify genes differentially expressed between the following: (1) the $\mathrm{N}$-sufficient to the mild $\mathrm{N}$-limiting samples ( $3 \mathrm{mM} \mathrm{N}$ to $1 \mathrm{mM} \mathrm{N}$ ); (2) the $\mathrm{N}$-sufficient to the severe $\mathrm{N}$-limiting samples ( $3 \mathrm{mM} \mathrm{N}$ to $0.3 \mathrm{mM} \mathrm{N})$; (3) severe $\mathrm{N}(0.3 \mathrm{mM} \mathrm{N})$ to the $2 \mathrm{hr} \mathrm{N}$ induction samples; and (4) severe $\mathrm{N}(0.3 \mathrm{mM} \mathrm{N})$ to the $24 \mathrm{hr} \mathrm{N}$ induction samples. Different numbers of significant genes could be obtained depending on the SAM median false discovery rate (FDR). The final number of significant genes of the following analyses was based on a median FDR of $0 \%$ and a minimum of a 2 -fold expression difference (Table 1). To confirm the results of the microarray analysis, the expression of 14 significant genes (7 up-regulated and 7 down-regulated) was tested by semi-quantitative RT-PCR and found to be consistent with the microarray data [see Additional file 1].

\section{Functional classification of significant genes under mild and severe chronic $\mathbf{N}$ stress}

Although plant growth measured by shoot biomass was reduced by $20 \%$ under mild $\mathrm{N}$ stress, the baseline expression levels of most genes in the genome remained similar. Only 52 genes were identified with expression levels significantly different, of which 51 were induced and one suppressed in the mild $\mathrm{N}$-limiting condition compared to the N-sufficient condition. However, when the degree of this chronic $\mathrm{N}$ stress increased, these numbers increased dramatically. A total of 461 genes showed significant response, of which 271 genes were up-regulated and 190 genes down-regulated under the severe N-limiting condition, when plant growth was reduced by $65 \%$ measured by shoot biomass. Severe $\mathrm{N}$ stress introduced a much greater transcriptional changes compared to mild $\mathrm{N}$ stress. This result is similar to the microarray study on plants under different degrees of phosphate deficiency [36]. In that case, 72 genes were induced and four genes were suppressed during short-term Pi deprivation, and the numbers increased to 291 genes induced and 34 genes suppressed during medium-term Pi starvation, and further increased to 501 genes induced and 231 genes suppressed during long-term deficiency [36].

The entire gene lists under the mild and severe N-limiting conditions are provided in Additional file 2 and 3 respectively, together with their functional and pathway assignments. Functional assignments are defined by Gene Ontology (GO) terms [37], which provide broad functional classifications for genes and gene products representing their corresponding biological processes, molecular function, and cellular localization. Pathway assignments are derived from the Kyoto Encyclopedia of Genes and Genomes (KEGG) [38]. Gene ontology on the Arabidopsis Information Resource website [39], and a browser-based functional classification program [40] were also consulted.

Under the mild $\mathrm{N}$-limiting condition when plant growth was slightly reduced, none of the genes directly involved in nitrate assimilation showed significant changes in expression (Table 2). However, when plants were grown under the severe N-limiting condition, many primary metabolism genes including those involved in $\mathrm{N}$ assimilation were significantly down-regulated. In terms of the nitrate assimilatory genes, the baseline expressions of $N R 1, N R 2$ and NiR were clearly correlated with the three $\mathrm{N}$ levels - the lower the $\mathrm{N}$ concentration, the lower the baseline expression (Table 2). This indicates that the degree of the reduction of $\mathrm{N}$ assimilation gene expression is correlated to the amount of $\mathrm{N}$ available. As for the ammonium assimilatory genes, GS1-1 and GS1-4, the opposite trend of the nitrate assimilation genes (NR1, NR2 and NiR) was observed. GS1-1 and GS1-4 were upregulated under severe $\mathrm{N}$ stress (Table 2). GS has a very high affinity for ammonia and catalyzes the ATP-dependent conversion of glutamate into glutamine by incorporating a molecule of ammonia. The individual isoenzymes of GS and GOGAT have been proposed to play roles in three

Table I: Significant gene numbers at different cutoff levels

\begin{tabular}{cccc}
\hline & FDR 0.5\% & FDR 0\% & FDR 0\% minimum 2 fold \\
\hline Sufficient N vs. mild N & 157 & 120 & $52\left(\left.5\right|^{\mathrm{a}},\left.\right|^{\mathrm{b}}\right)$ \\
Sufficient N vs. severe N & 2176 & $46 \mid$ & $46 \mid\left(\left.27\right|^{\mathrm{a}}, 190^{\mathrm{b}}\right)$ \\
Severe N vs. 2 hr induction & 146 & 90 & $90\left(77^{\mathrm{a}}, 13^{\mathrm{b}}\right)$ \\
Severe N vs. 24 hr induction & 2523 & 905 & $837\left(\left.48\right|^{\mathrm{a}}, 356^{\mathrm{b}}\right)$ \\
\hline
\end{tabular}

Significance analysis of microarray (SAM; academic version 2.23B) was used to identify differentially expressed genes. Different number of significant genes could be obtained depending on the SAM median false discovery rate (FDR) and a minimum fold change. a number of genes up-regulated; b number of genes down-regulated 
major ammonium assimilation processes: (1) primary nitrogen assimilation; (2) re-assimilation of photorespiratory ammonia; and (3) re-assimilation of "recycled" nitrogen [41]. Since primary metabolism such as nitrogen assimilation, photosynthesis and photorespiration is repressed under severe $\mathrm{N}$ stress, it is likely that the increased expression of cytosolic GS1 is related to the reassimilation of ammonia released from protein degradation which usually occurs under $\mathrm{N}$ deficiency. With regard to the $\mathrm{N}$ uptake genes, different trends were observed among members of the low affinity nitrate transporter gene family NRT1. NRT1.1 baseline expression was higher, while NRT1.3 and NRT1.4 baselines expression were lower under $\mathrm{N}$ stress (Table 2), suggesting a lack of functional redundancy among family members. In addition to the $\mathrm{N}$ assimilation genes, those involved in the nitrate storage were deeply repressed by $\mathrm{N}$ deficiency. An anion channel protein gene, which was recently demonstrated to mediate nitrate accumulation in plant vacuoles [42], was down-regulated almost 7-fold under severe $\mathrm{N}$ shortage while no significant difference in expression was observed under mild $\mathrm{N}$ limitation (Table 3 ).

$\mathrm{N}$ stress led to marked changes in the expression of genes involved in carbon metabolism. Genes involved in photosynthesis, including those that code for the photosystem II family protein, the oxygen evolving enhancer 3 PsbQ family protein, the PSI type II chlorophyll a b-binding protein, and the photosystem II reaction centre W PsbW family protein were significantly down-regulated under the severe $\mathrm{N}$-limiting condition, but not the mild N-limiting condition (Table 3 ). In addition, genes involved in the oxidative pentose-phosphate pathway that provide reducing power (NADPH) and pentose phosphates were downregulated, including the gene coding for glucose-6-phosphate 1-dehydrogenase, which is the rate-limiting step in this process (Table 3 ). On the other hand, genes involved in the accumulation of starch, including ADP-glucose pyrophosphorylase which catalyzes the first, rate-limiting step in starch biosynthesis, were significantly up-regulated under severe $\mathrm{N}$ stress (Table 3 ).

$\mathrm{N}$ stress induces profound changes to growth and development. In order to adapt to the growth arrest due to severe $\mathrm{N}$ deficiency, many ribosomal genes involved in protein biosynthesis were down-regulated, including genes coding for structural constituents of ribosome and translation elongation factors [see Additional file 3]. At the same time, genes involved in protein degradation were up-regulated under severe $\mathrm{N}$ stress, such as the Cys peptidase (SAG12) (Table 3). It is believed that during nutrient deficiency, plants transport a series of cytosolic proteins into the vacuole, where various proteases are located, to be degraded into amino acids and exported from senescing tissues for cell reuse.
As expected, there were marked changes in the expression of genes involved in hormone synthesis and sensing since they largely control plant growth. Auxin stimulates cell devision and elongation, and many auxin-induced genes were down-regulated under severe $\mathrm{N}$ stress [see Additional file 3]. Cytokinin regulates cell proliferation and differentiation, and many cytokinin-responsive genes were downregulated under severe $\mathrm{N}$ stress, including two transcription regulators (At3g48100, At2g18300) (Table 3).

Leaf yellowing is one of the typical responses plants have when $\mathrm{N}$ deficiency occurs [43]. While chlorophyll levels were slightly reduced ( $\sim 5 \%$ reduction) under the mild $N$ limiting condition, none of the chlorophyll biosynthesis genes changed appreciably at the transcriptional level, indicating a disconnection between transcriptional responses and phenotypic changes. Under the severe $\mathrm{N}$ limiting condition, the chlorophyll levels were significantly reduced ( $\sim 30 \%$ reduction). Genes involved in chlorophyll metabolism were down-regulated, including protochlorophyllide reductase, protochlorophyllide reductase and hydroxymethylbilane synthase (Table 3 ).

$\mathrm{N}$ stress induced a number of plant stress responses. Many genes involved in various stress responses were up-regulated, including some peroxidase genes and glutathioneStransfeerase (GST) genes under both N-limiting conditions [see Additional file 2 and 3]. Toxic nitrogen compounds are usually generated under various stresses. Nitrilase 4, of which the purified enzyme has been shown to be involved in the nitrogen compound detoxification pathway, was up-regulated around 3-fold under mild $\mathrm{N}$ stress, but up-regulated over 11-fold under severe $\mathrm{N}$ stress (Table 3).

The presence of the purple flavonoid anthocyanin is an indicator of stress [44], and $\mathrm{N}$ deficiency may lead to increased anthocyanin synthesis [43]. Plants were obviously purple in color under the severe N-limiting condition (not shown). Genes involved in anthocyanin synthesis, such as leucoanthocyanidin dioxygenase and dihydroflavonol reductase, were up-regulated just over 2fold under mild $\mathrm{N}$ stress, but increased to about 14 - and 18 -fold under severe $\mathrm{N}$ stress (Table 3 ). Chalcone synthase, which participates in the biosynthetic pathway for all flavonoids and is required for the accumulation of anthocyanins, was up-regulated only under severe $\mathrm{N}$ stress (Table 3). The expression of the Myb transcription factor PAP1 was increased about 6-fold under severe N stress, and the expression of the Myb transcription factor PAP2 was increased around 3-fold under the mild N-limiting condition, but dramatically increased to over 26-fold under the severe $\mathrm{N}$-limiting condition (Table 3 ). The two Myb genes have been shown to be able to regulate flavonoid and anthocyanin biosynthesis and over-expression 
Table 2: Expression of nitrate assimilation genes under different $\mathbf{N}$ conditions

\begin{tabular}{|c|c|c|c|c|c|c|}
\hline Genes & & Locus & $\begin{array}{l}\text { Fold } \\
\text { limiting }\end{array}$ & $\begin{array}{l}\text { Fold } \\
\text { stress }\end{array}$ & Fold $2 \mathrm{hr}$ & $\begin{array}{c}\text { Fold } 24 \\
\mathrm{hr}\end{array}$ \\
\hline \multicolumn{7}{|c|}{ Nitrate transport } \\
\hline \multirow[t]{4}{*}{ Low-affinity nitrate transporter } & NRTI.I & At $\lg 12110$ & 1.3 & 1.8 & 1.8 & -1.3 \\
\hline & NRTI.2 & Atlg69850 & - & - & - & - \\
\hline & NRTI.3 & At3g2 1670 & -1.1 & -2.1 & 1.0 & 1.6 \\
\hline & NRTI.4 & At2g26690 & -1.1 & -2.1 & 1.2 & $2.4^{*}$ \\
\hline \multirow[t]{7}{*}{ High-affinity nitrate transporter } & NRT2.I & Atlg08090 & - & - & - & - \\
\hline & NRT2.2 & Atlg08100 & - & - & - & - \\
\hline & NRT2.3 & At5g60780 & - & - & - & - \\
\hline & NRT2.4 & At5g60770 & - & - & - & - \\
\hline & NRT2.5 & Atlg/2940 & - & - & - & - \\
\hline & NRT2.6 & At3g45060 & - & - & - & - \\
\hline & NRT2.7 & At5g/4570 & - & - & - & - \\
\hline \multicolumn{7}{|c|}{ Nitrate reduction } \\
\hline Nitrate reductase I (NRI) & & At $\lg 77760$ & -1.2 & -1.9 & $\mid \mathrm{II} \mathrm{I}^{*}$ & 1.5 \\
\hline Nitrate reductase 2 (NR2) & & At $\lg 37 / 30$ & -1.2 & $-3.3^{*}$ & $8.1 *$ & $2.9 *$ \\
\hline Nitrite reductase (NiR) & & At2g15620 & -1.2 & $-4.4^{*}$ & $15.1^{*}$ & $3.2^{*}$ \\
\hline $\begin{array}{c}\text { urophorphyrin III methylase } \\
\text { (UPMI) }\end{array}$ & & At5g40850 & 1.0 & -1.5 & $10.1^{*}$ & 1.5 \\
\hline \multirow[t]{6}{*}{ Fd NADP $(+)$ reductase (FNR) } & & At4g05390 & 1.3 & 1.2 & $3.6^{*}$ & 1.0 \\
\hline & & Atlg30510 & 1.1 & 1.1 & $3.1^{*}$ & 1.0 \\
\hline & & At4g32360 & - & - & - & - \\
\hline & & At5g66190 & - & - & - & - \\
\hline & & Atlg20020 & - & - & - & - \\
\hline & & At5g66810 & - & - & - & - \\
\hline \multicolumn{7}{|c|}{ Ammonia assimilation } \\
\hline \multirow[t]{5}{*}{ Glutamine synthetase } & GSI-I & At5g37600 & 1.7 & $4.7 *$ & -1.6 & $-3.4^{*}$ \\
\hline & GSI-2 & Atlg66200 & - & - & - & - \\
\hline & GSI-3 & At3gl 7820 & - & - & - & - \\
\hline & $G S I-4$ & At5gl6570 & 1.7 & $6.9 *$ & -2.0 & $-3.7^{*}$ \\
\hline & GSI-5 & Atlg48470 & - & - & - & - \\
\hline \multirow[t]{4}{*}{ Glutamate synthetase } & GS2 & At5g35630 & - & - & - & - \\
\hline & GOGATI & At5g04/40 & - & - & - & - \\
\hline & GOGAT2 & At2g4/220 & - & - & - & - \\
\hline & GOGAT3 & At5g53460 & - & - & - & - \\
\hline \multirow[t]{3}{*}{ Asparagines synthetase } & ASI & At3g47340 & - & - & - & - \\
\hline & AS2 & At5g65010 & -1.3 & $-3.2^{*}$ & $7.6^{*}$ & $2.9 *$ \\
\hline & AS3 & At5g 10240 & - & - & - & - \\
\hline
\end{tabular}

Fold changes under different $N$ conditions were presented: sufficient $N$ vs. limiting $N$ (fold, limiting); sufficient $N$ vs. stress $N$ (fold, stress); stress $N$ vs. $2 \mathrm{hr}$ induction (fold, $2 \mathrm{hr}$ ); stress $\mathrm{N}$ vs. $24 \mathrm{hr}$ induction (fold, $24 \mathrm{hr}$ ). Negative number means gene expression down-regulated in said condition, and positive number means gene expression up-regulated in said condition. *significant from our SAM analysis;

---- no fluctuation under all $\mathrm{N}$ conditions

of the Myb genes resulted in an enhanced accumulation of lignin and flavonoids, including various anthocyanins that produce purple color [45]. It is clear that the accumulation of anthocyanins is closely correlated with the level of $\mathrm{N}$ stress, and PAP1 and PAP2 are involved in the regulation of this process. However, it is unclear how specific this regulation is for $\mathrm{N}$ stress response.

As $\mathrm{N}$ deficiency responses are known to be regulated at the transcriptional level, transcriptional factor genes were looked up from the entire gene lists [see Additional file 2 and 3]. Three transcription factors genes were induced under mild $\mathrm{N}$ limitation, including a WRKY transcription factor (At1g80840), an ethylene responsive element binding factor 2 (ATERF-2, At5g47220) and the aforementioned Myb transcription factor (PAP2) gene [see Additional file 2]. Plant proteins containing WRKY or ATERF domains are known regulators of abiotic and biotic stress responses $[46,47]$. Detailed characterization of the WRKY gene (At1g80840) is lacking, but the ATERF2 gene (At5g47220) is known to be regulated by other abiotic stress conditions [48]. Thirty-nine transcription factor genes were significantly induced or repressed under severe $\mathrm{N}$ stress, including the Myb factors PAP1 and PAP2, the two cytokinin-responsive transcription regulators (At3g48100, At2g18300) mentioned earlier, and three 
Table 3: Expression of selected significant genes under different $\mathbf{N}$ conditions

\begin{tabular}{|c|c|c|c|c|c|c|}
\hline Functional classification & Locus & Gene identification & $\begin{array}{c}\text { Fold } \\
\text { limitin } \\
g\end{array}$ & $\begin{array}{l}\text { Fold } \\
\text { stress }\end{array}$ & $\begin{array}{c}\text { Fold } 2 \\
\mathrm{hr}\end{array}$ & $\begin{array}{c}\text { Fold } 24 \\
\mathrm{hr}\end{array}$ \\
\hline nitrate accumulation & At5g40890 & anion channel protein & ns & -6.8 & 2.9 & 6.0 \\
\hline \multirow[t]{2}{*}{ photosynthesis } & Atlg03600 & photosystem II family protein & ns & -2.9 & ns & 2.3 \\
\hline & At4g28660 & photosystem II protein W & ns & -2.7 & ns & 3.2 \\
\hline \multirow[t]{2}{*}{ pentose-phosphate pathway } & At5g35790 & $\begin{array}{l}\text { glucose-6-phosphate I- } \\
\text { dehydrogenase }\end{array}$ & ns & -2.6 & ns & 2.3 \\
\hline & At $\lg 24280$ & $\begin{array}{l}\text { glucose-6-phosphate I- } \\
\text { dehydrogenase }\end{array}$ & ns & ns & 5.2 & ns \\
\hline \multirow[t]{2}{*}{ starch synthesis } & At4g39210 & ADP-glucose pyrophosphorylase & ns & 3.9 & ns & -4.1 \\
\hline & At2g21590 & ADP-glucose pyrophosphorylase & ns & 2.8 & ns & -3.1 \\
\hline \multirow[t]{3}{*}{ chlorophyll synthesis } & Atlg03630 & protochlorophyllide reductase & ns & -2.9 & ns & 2.8 \\
\hline & At4g27440 & protochlorophyllide reductase & ns & -2.9 & ns & 2.3 \\
\hline & At5g08280 & hydroxymethylbilane synthase & ns & -2.6 & ns & 2.7 \\
\hline protein degradation & At5g45890 & $\begin{array}{l}\text { senescence-specific cysteine } \\
\text { protease SAGI } 2\end{array}$ & ns & 7.7 & ns & -4.3 \\
\hline nitrogen detoxification & At5g22300 & nitrilase 4 & 2.8 & 11.5 & ns & -4.4 \\
\hline \multirow[t]{5}{*}{ anthocyanin synthesis } & At4g22880 & leucoanthocyanidin dioxygenase & 2.1 & 14.4 & ns & -7.8 \\
\hline & At5g42800 & dihydroflavonol 4-reductase & 3.3 & 18.7 & ns & -8.3 \\
\hline & At5g/3930 & chalcone synthase & ns & 4.1 & ns & -3.4 \\
\hline & Atlg 56650 & Myb transcription factor PAPI & ns & 6.3 & -3.0 & -6.3 \\
\hline & Atlg66390 & Myb transcription factor PAP2 & 3.5 & 26.6 & -6.7 & -16.7 \\
\hline phenylpropanoid synthesis & At2g37040 & phenylalanine ammonia lyase & ns & 4.1 & ns & -3.2 \\
\hline \multirow[t]{3}{*}{ response to cytokinin } & At3g63110 & cytokinin synthase & ns & ns & 3.6 & ns \\
\hline & At3g48100 & transcription repressor & ns & -4.3 & 3.7 & 3.6 \\
\hline & At2gl8300 & transcription factor & ns & -8.4 & 7.9 & 6.8 \\
\hline \multirow[t]{4}{*}{ transcription } & Atlg30500 & CCAAT transcription factor & ns & 4.3 & ns & -4.3 \\
\hline & At2g34720 & CCAAT transcription factor & ns & 3.4 & ns & -3.0 \\
\hline & At3g05690 & CCAAT transcription factor & ns & 3.8 & ns & ns \\
\hline & At5g 47220 & ATERF2 transcription factor & 2.0 & 2.4 & ns & ns \\
\hline
\end{tabular}

Fold changes under different $\mathrm{N}$ conditions were presented: sufficient $\mathrm{N}$ vs. limiting $\mathrm{N}$ (fold, limiting); sufficient $\mathrm{N}$ vs. stress $\mathrm{N}$ (fold, stress); stress $\mathrm{N}$ vs. $2 \mathrm{hr}$ induction (fold, $2 \mathrm{hr}$ ); stress $\mathrm{N}$ vs. $24 \mathrm{hr}$ induction (fold, $24 \mathrm{hr}$ ). Negative number means gene expression down-regulated in said condition, and positive number means gene expression up-regulated in said condition. ns - not significant from our SAM analysis

genes (At1g30500, At2g34720 and At3g05690) coding for CCAAT binding factor complex (Table 3 ). While members in this CCAAT family are known to be involved in developing the tolerance of plants to various abiotic stress conditions [49-51], mechanistic details about these CCAAT genes and their possible specific involvement in $\mathrm{N}$ stress tolerance need further investigation. Some Myb transcription factors were down-regulated under severe $\mathrm{N}$ stress, including two Myb factors (At1g25550 and At1g68670), and some were up-regulated (PAP1 and PAP2), indicating the divergent function of individual members within this transcription factor gene family.

Overall, mild N stress triggered only a small set of genes to be expressed significantly differently. These genes are largely involved in various stress responses, including genes involved in anthocyanin biosynthesis. There is a possible disconnect between transcriptional responses and phenotypic changes, as no genes specifically involved in growth arrest or chlorophyll synthesis have significantly altered expression levels. Thus, it appears that there was a compensatory response to this limited level of $\mathrm{N}$ stress. Under severe $\mathrm{N}$ stress, however, plant responses were much more pronounced. Table 4 summarizes some of the biological processes with significant genes over-represented in the two $\mathrm{N}$ stress responses $(\mathrm{P}<0.01)$. Among the up-regulated genes under mild $\mathrm{N}$ stress, 16 genes, or $40 \%$ of the significant gene list (excluding genes of unknown functions), belong to the "response to abiotic stimulus" process according to GO. Genome-wide, there are 1091 member genes in this process, or $6 \%$ of the genome. Apparently, mild $\mathrm{N}$ stress invoked a significant response from abiotic stimulus related pathways (P-value $=4.2 \mathrm{E}-10)$. Fourteen genes, or $35 \%$ of the list, are responsive to different type of stress, including 5 of those responsive to oxidative stress. Six genes, or $15 \%$ of the list, are involved in secondary metabolism, including two for flavonoid biosynthesis and two for anthocyanin biosynthesis. Under severe $\mathrm{N}$ stress, up-regulated genes are still overrepresented by those involved in the response to abiotic stimulus and other types of stress as well as secondary metabolism. However, the relative percentage of these 
"stress genes" actually decreased when many more genes responded transcriptionally to severe $\mathrm{N}$ stress and many of them are involved in other processes, such as the response to abscisic acid stimulus, phenylpropanoid biosynthesis, senescence and starch biosynthesis (Table 4). Genes involved in primary metabolism had a preponderance of down-regulated genes under severe $\mathrm{N}$ stress. Fiftyeight genes, or $43 \%$ of the list, belong to that category, including 7 involved in nitrogen compound metabolism and 4 in the main pathways of carbohydrate metabolism (Table 4). Twenty-eight biosynthetic genes, or about $20 \%$ of the list, are down-regulated, with 17 of these involved in protein biosynthesis. Down-regulated genes are also involved in photosynthesis, the response to auxin and cytokinin and the generation of precursor metabolites and energy (Table 4). The number of genes with significantly altered expression in each of these processes and their degrees of over-representation is noted in Table 4.

Around $50 \%$ of the genes with significantly altered expression from the mild N-limiting condition overlap with the genes from the severe N-limiting condition. The overlapping gene list is provided in Additional file 4. Many of these genes are involved in the response to abiotic or biotic stress, such as peroxidases, GST genes and genes involved in anthocyanin synthesis, pointing to possible interactions between general stress and $\mathrm{N}$ stress. Two transcription factors PAP2 and ATERF2 (At5g47220) are present in both lists. Some of the overlapping genes such as PAP2 responded much more strongly at the transcript level under severe $\mathrm{N}$ stress, while others such as the ATERF2 gene responded at a similar level under both conditions (Table 3). Therefore, plants might have a unique scaled response system for different degrees of $\mathrm{N}$ stress by a gradual activation of genes from mild to severe $\mathrm{N}$ stress.

\section{Functional classification of significant genes after short- and long-term $\mathbf{N}$ availability increase}

Three-week-old Arabidopsis plants grown under severe N stress were transferred to the sufficient $\mathrm{N}$ condition and harvested after 2 and 24 hrs. After 2 hrs of increased N availability, a total of 77 genes were significantly up-regulated and 13 genes were significantly down-regulated. Twenty-four hrs of increased $\mathrm{N}$ availability invoked a greater plant response as the expression levels of 481 genes were significantly up-regulated and 356 were significantly down-regulated. The significant gene lists are provided in Additional file 5 and 6 respectively, together with their functional and pathway assignments. The short-term $\mathrm{N}$ availability increase triggered a rapid response of many genes directly involved in plant growth and development. The nitrate assimilatory genes, NR1, NR2 and NiR, were up-regulated significantly after a $2 \mathrm{hr} \mathrm{N}$ induction, followed by a drop after $24 \mathrm{hr}$ (Table 2), a pattern consistent with previous reports. The UPM1 gene, which encodes an enzyme that makes a cofactor for $\mathrm{NiR}$, had a very similar trend as NiR (Table 2). Two FNR genes, involved in supplying reductant to $\mathrm{NiR}$, also had a transient increase (Table 2). With regard to the $\mathrm{N}$ uptake genes, the low affinity nitrate transporter gene NRT1.1 showed some increase after $2 \mathrm{hr} \mathrm{N}$ induction, while NRT1.4 showed significant induction after $24 \mathrm{hr}$ (Table 2), suggesting a different role played by individual transporters in $\mathrm{N}$ response. Surprisingly, none of the seven NRT2 members showed significant change (Table 2). High affinity nitrate transporters (eg. NRT2.1) were induced significantly from $\mathrm{N}$-starved seedlings $[19,20]$, but not in our experiments, possibly due to the fact that plants in this study were grown at a constant low level of nitrate, rather than being $\mathrm{N}$-starved prior to the addition of a high level of nitrate. The expression of GS and GOGAT, the principle players in ammonium assimilation, didn't change significantly after $2 \mathrm{hr}$. GS1-1 and GS1-4 were repressed after the $24 \mathrm{hr}$ induction (Table 2), which is similar to the previous report [20]. Asparagine synthetase (AS) plays an important role in amino acid synthesis [41]. Among the three AS genes, AS2 (At5g65010) showed a very similar pattern to the nitrate reduction genes (NR1, NR2 and NiR) (Table 2 ). Genes involved in nitrate storage were significantly upregulated. The anion channel protein gene, mediating nitrate accumulation in plant vacuoles [42], was up-regulated around 3-fold after $2 \mathrm{hr}$ of $\mathrm{N}$ addition and continued to increase to 6 -fold after $24 \mathrm{hr}$ (Table 3 ).

Many genes involved in carbon metabolism were up-regulated with increased $\mathrm{N}$ availability. Sugar transporter genes were up-regulated after $2 \mathrm{hr}$, together with some amino acid transporters [see Additional file 5]. The expression of the genes coding for the rate-limiting step of the oxidative pentose-phosphate pathway glucose-6phosphate 1-dehydrogenase was induced. However, the two genes coding for the two isozymes showed a different pattern with one being induced only after $2 \mathrm{hrs}$ and the other only after 24 hrs of increased $\mathrm{N}$ availability (Table 3 ). Genes involved in photosynthesis (photosystem II family protein and photosystem II reaction centre $\mathrm{W}$ PsbW family protein) were significantly up-regulated, and genes involved in the accumulation of starch (ADP-glucose pyrophosphorylase) were down-regulated only in the $24 \mathrm{hr}$ induction samples (Table 3). Phytohormone genes coding for cell growth and expansion were induced, such as adenylate isopentenyl transferase 3 (cytokinin synthase 3, At3g63110) (Table 3). In addition, genes involved in sulphate metabolism and in iron acquisition, transport and homeostasis were all up-regulated $2 \mathrm{hrs}$ after increased $\mathrm{N}$ availability (see Additional file 5). Seven transcription factor genes were significantly induced or repressed after short-term $\mathrm{N}$ induction $(2 \mathrm{hr}$ ) [see Additional file 5], including up-regulated Myb transcriptional 
Table 4: Biological processes with significant genes over-represented under mild or severe chromic $\mathbf{N}$ stress

\begin{tabular}{|c|c|c|c|c|c|c|c|c|}
\hline \multirow{2}{*}{$\begin{array}{l}\text { Biological } \\
\text { Process }\end{array}$} & \multirow{2}{*}{$\begin{array}{l}\text { No. in } \\
\text { Genome }\end{array}$} & \multirow{2}{*}{$\begin{array}{c}\% \text { in } \\
\text { Genome }\end{array}$} & \multicolumn{3}{|c|}{ Under mild $\mathrm{N}$ stress } & \multicolumn{3}{|c|}{ Under severe $\mathrm{N}$ stress } \\
\hline & & & $\begin{array}{l}\text { No. in } \\
\text { List }\end{array}$ & $\%$ in List & P-value & $\begin{array}{l}\text { No. in } \\
\text { List }\end{array}$ & $\%$ in List & P-value \\
\hline \multicolumn{9}{|l|}{$\begin{array}{l}\text { Up- } \\
\text { regulated }\end{array}$} \\
\hline $\begin{array}{l}\text { response to } \\
\text { abiotic } \\
\text { stimulus }\end{array}$ & 1091 & 6.0 & 16 & 40 & $4.2 \mathrm{E}-10$ & 39 & 19.3 & 7.3E-II \\
\hline $\begin{array}{l}\text { response to } \\
\text { stress }\end{array}$ & 945 & 5.2 & 14 & 35 & $6.4 \mathrm{E}-09$ & 23 & 11.4 & 0.0004 \\
\hline $\begin{array}{l}\text { secondary } \\
\text { metabolism }\end{array}$ & 249 & 1.4 & 6 & 15 & $1.6 \mathrm{E}-05$ & 15 & 7.4 & I.3E-07 \\
\hline $\begin{array}{l}\text { response to } \\
\text { oxidative } \\
\text { stress }\end{array}$ & 140 & 0.8 & 5 & 12.5 & I.4E-05 & 8 & 4.0 & 0.0002 \\
\hline $\begin{array}{c}\text { flavonoid } \\
\text { biosynthesis }\end{array}$ & 30 & 0.2 & 2 & 5 & 0.002 & 6 & 3.0 & 8.4E-07 \\
\hline $\begin{array}{l}\text { anthocyanin } \\
\text { biosynthesis }\end{array}$ & 8 & 0.04 & 2 & 5 & 0.007 & 3 & 1.5 & 7.3E-05 \\
\hline $\begin{array}{l}\text { phenylpropan } \\
\text { oid } \\
\text { biosynthesis }\end{array}$ & 79 & 0.4 & & & & 9 & 4.5 & $2.3 \mathrm{E}-07$ \\
\hline $\begin{array}{l}\text { response to } \\
\text { abscisic acid } \\
\text { stimulus }\end{array}$ & 113 & 0.6 & & & & 9 & 4.5 & $4.8 \mathrm{E}-06$ \\
\hline $\begin{array}{c}\text { organ } \\
\text { senescence }\end{array}$ & 12 & 0.07 & & & & 3 & 1.5 & 0.0003 \\
\hline $\begin{array}{c}\text { starch } \\
\text { biosynthesis }\end{array}$ & 7 & 0.04 & & & & 2 & 1.0 & 0.002 \\
\hline \multicolumn{9}{|l|}{$\begin{array}{l}\text { Down- } \\
\text { regulated }\end{array}$} \\
\hline $\begin{array}{c}\text { primary } \\
\text { metabolism }\end{array}$ & 5170 & 28.5 & & & & 58 & 43.0 & 0.0002 \\
\hline biosynthesis & 1269 & 7.0 & & & & 28 & 20.7 & I.6E-07 \\
\hline $\begin{array}{l}\text { protein } \\
\text { biosynthesis }\end{array}$ & 500 & 2.8 & & & & 17 & 12.6 & $1.9 \mathrm{E}-07$ \\
\hline $\begin{array}{l}\text { response to } \\
\text { auxin stimulus }\end{array}$ & 191 & I.I & & & & 10 & 7.4 & 1.7E-06 \\
\hline $\begin{array}{l}\text { generation of } \\
\text { precursor } \\
\text { metabolites } \\
\text { and energy }\end{array}$ & 451 & 2.5 & & & & 10 & 7.4 & 0.002 \\
\hline $\begin{array}{l}\text { nitrogen } \\
\text { compound } \\
\text { metabolism }\end{array}$ & 276 & 1.5 & & & & 7 & 5.2 & 0.005 \\
\hline $\begin{array}{l}\text { response to } \\
\text { cytokinin } \\
\text { stimulus }\end{array}$ & 31 & 0.2 & & & & 5 & 3.7 & 3.IE-06 \\
\hline $\begin{array}{c}\text { main } \\
\text { pathways of } \\
\text { carbohydrate } \\
\text { metabolism }\end{array}$ & 95 & 0.5 & & & & 4 & 3.0 & 0.006 \\
\hline $\begin{array}{l}\text { photosynthesi } \\
\text { s }\end{array}$ & 44 & 0.2 & & & & 3 & 2.2 & 0.004 \\
\hline
\end{tabular}

The gene list was imported into GeneSpring. The number of genes in each biological process either in a whole genome (No. in Genome), or in the list (No. in list), as well as their corresponding percentage and p-value was generated by GeneSpring. 
factor genes (At3g46130, At1g25550 and At1g68670) and down-regulated PAP1 and PAP2 genes.

Table 5 summarizes some biological processes over-represented in genes responding to short- and long-term $\mathrm{N}$ availability increase $(\mathrm{P}<0.01)$. When $\mathrm{N}$ was transiently increased, genes involved in transporter activities were upregulated. Eleven of these genes, or $20 \%$ of the significant gene list (excluding unknown function genes), belong to the "transport" process according to GO. Genome-wide, there are 1398 member genes in this process, or close to $8 \%$ of the genome, indicating a clear increase in $\mathrm{N}$ stimulated nutrient transport activities $(P$-value $=0.002)$. Genes involved in nitrogen assimilation, carbon metabolism, sulfate assimilation and cell homeostasis were simultaneously up-regulated after a short-term $\mathrm{N}$ increase (Table 5). The up-regulated genes are over-represented in the process "response to cytokinin stimulus" after both the short- and longer-term $\mathrm{N}$ increase (Table 5). After the $24 \mathrm{hr} \mathrm{N}$ increase, 203 genes involved in primary metabolism, or $54.7 \%$ of the significant gene list, were up-regulated, and 121 genes involved in protein biosynthesis, or $32.61 \%$ of the list, were up-regulated (Table 5). Other processes with over-represented up-regulated genes include those involved in nitrogen compound biosynthesis, chlorophyll biosynthesis, organelle organization and biogenesis, DNA packaging, nucleosome assembly, ribonucleotide biosynthesis, translation, and the responses to auxin stimulus (Table 5). On the other hand, down-regulated genes are over-represented in processes such as flavonoid biosynthesis, phenylpropanoid biosynthesis, anthocyanin biosynthesis and starch biosynthesis (Table 5), reflecting the shift from secondary to primary metabolism when more $\mathrm{N}$ became available. Down-regulation of anthocyanin biosynthetic genes was also observed after the shorterterm $\mathrm{N}$ increase (Table 5). The expression of many genes was significantly altered only after longer-term $\mathrm{N}$ increase, suggesting some of the changes may result from a secondary response. The expression levels of many genes fluctuated, some quite dramatically, in response to different degrees of $\mathrm{N}$ stress or different lengths of $\mathrm{N}$ induction. The most striking change was found with the Myb factor PAP2 (At1g66390), which was up-regulated over 3-fold under mild $\mathrm{N}$ stress, up-regulated 26 -fold under severe $\mathrm{N}$ stress, down-regulated $\sim 7$-fold after a $2 \mathrm{hr} \mathrm{N}$ increase and continued to fall by over 16 -fold after the $24 \mathrm{hr} \mathrm{N}$ increase (Table 3 ), indicating the close correlation between anthocyanin biosynthesis and $\mathrm{N}$ availability.

\section{Comparison with published microarray data}

Wang et al [19] published microarray data for roots and shoots of Arabidopsis seedlings grown in a "pure" hydroponic system for $10 \mathrm{~d}$ on ammonium and then supplied with $0.25 \mathrm{mM}$ nitrate for $20 \mathrm{~min}$. They found that a total of 76 genes were up-regulated and 2 genes were down-reg- ulated using a cutoff value of 2-fold change in shoots. Scheible et al [20] revealed genes affected by $\mathrm{N}$-induction after $30 \mathrm{~min}$ or $3 \mathrm{hr}$ from N-starved seedlings. The induction patterns and the majority of the nitrate-induced genes of our study overlap with their findings $[19,20]$. Most of the nitrate assimilation genes were induced in a similar fashion, such as NR1, NR2, NiR, UPM1 and two of the six FNR genes [19]. However, high affinity nitrate transport gene (NRT2.1) was induced significantly from $\mathrm{N}$-starved seedlings $[19,20]$, but not in our experiments. This is likely due to the different system used. Rather than being $\mathrm{N}$-starved prior to the addition of a high level of nitrate, plants used in the current study were grown on a constant low level of nitrate, and there was some storage of free nitrate in the plants (Figure 1b). Our data presented here were from samples taken in the middle of the day to minimize diurnal effects, as nitrate levels in the plants could still fluctuate at dawn and at night and thus cause some corresponding transcriptional changes [52].

Wang et al [19] identified 6 transcription factor genes in shoots at least 2-fold induced or repressed after $20 \mathrm{~min}$ induction. In N-starved seedlings, Scheible et al. [20] identified 37 and 42 transcription factor genes, with altered expression after $30 \mathrm{~min}$ or $3 \mathrm{hr} \mathrm{N}$ induction respectively, with at least a 3 -fold change. We identified 7 transcription factor genes significantly induced or repressed after shortterm $\mathrm{N}$ induction $(2 \mathrm{hr})$, all of which overlap with Scheible's gene list [20].

Additionally, Scheible et al [20] discovered 55 transcription factor genes at least 3-fold induced or repressed in the $\mathrm{N}$-starved seedlings. We identified 3 transcription factor genes significantly induced or repressed under mild $\mathrm{N}$ stress and 39 under severe $\mathrm{N}$ stress. However, 70\% of those genes (two of the three from mild $\mathrm{N}$ stress, and 27 of the 39 from severe N stress) do not overlap with Scheible's gene list [20], indicating that plants have a very different regulatory system to cope with $\mathrm{N}$ starvation versus chronic $\mathrm{N}$ stress. These transcription factor genes not reported previously were highlighted in the Additional Files 2 and 3.

Recently, Lian et al reported expression profiles of 10,422 genes at an early stage of low $\mathrm{N}$ stress in rice seedling [24]. They germinated and grew rice hydroponically with normal nutrient conditions until the emergence of the fourth leaf, then transferred the seedlings to a low $\mathrm{N}$ solution and harvested shoot and roots separately $20 \mathrm{~min}, 1$ and $2 \mathrm{hr}$ after the treatment. They found the down-regulation of genes involved in photosynthesis and energy metabolism as well as extensive cross-talk between the responses to low $\mathrm{N}$ stress and those to biotic and abiotic stresses. However, the genes involved in $\mathrm{N}$ uptake and assimilation remained unchanged, which is different from findings in 
Table 5: Biological processes with significant genes over-represented after short- and long-term $\mathbf{N}$ availability increase

\begin{tabular}{|c|c|c|c|c|c|c|c|c|}
\hline \multirow[t]{2}{*}{ Biological Process } & \multirow{2}{*}{$\begin{array}{l}\text { No. in } \\
\text { Genome }\end{array}$} & \multirow{2}{*}{$\begin{array}{l}\% \text { in } \\
\text { Genome }\end{array}$} & \multicolumn{3}{|c|}{$2 \mathrm{hr} \mathrm{N}$ increase } & \multicolumn{3}{|c|}{$24 \mathrm{hr} \mathrm{N}$ increase } \\
\hline & & & $\begin{array}{c}\text { No. } \\
\text { in } \\
\text { List }\end{array}$ & $\%$ in List & P-value & No. in List & $\%$ in List & P-value \\
\hline \multicolumn{9}{|l|}{ Up-regulated } \\
\hline transport & 1398 & 7.7 & II & 20.4 & 0.002 & & & \\
\hline cell homeostasis & 64 & 0.4 & 3 & 5.6 & 0.0009 & & & \\
\hline nitrate assimilation & 7 & 0.04 & 2 & 3.7 & 0.0002 & & & \\
\hline sulfate assimilation & 11 & 0.06 & 2 & 3.7 & 0.0005 & & & \\
\hline $\begin{array}{l}\text { response to carbohydrate } \\
\text { stimulus }\end{array}$ & 29 & 0.16 & 2 & 3.7 & 0.003 & & & \\
\hline primary metabolism & 5170 & 28.5 & & & & 203 & 54.7 & $1.0 \mathrm{E}-26$ \\
\hline protein biosynthesis & 500 & 2.8 & & & & 121 & 32.6 & $4.2 \mathrm{E}-98$ \\
\hline $\begin{array}{c}\text { organelle organization and } \\
\text { biogenesis }\end{array}$ & 439 & 2.4 & & & & 45 & 12.1 & $3.5 \mathrm{E}-19$ \\
\hline $\begin{array}{c}\text { ribosome biogenesis and } \\
\text { assembly }\end{array}$ & 117 & 0.6 & & & & 34 & 9.2 & $5.9 \mathrm{E}-30$ \\
\hline translation & 136 & 0.7 & & & & 13 & 3.5 & $4.4 \mathrm{E}-06$ \\
\hline response to auxin stimulus & 191 & I.I & & & & 12 & 3.2 & 0.0006 \\
\hline nucleosome assembly & 56 & 0.3 & & & & 9 & 2.4 & $1.8 \mathrm{E}-06$ \\
\hline DNA packaging & 106 & 0.6 & & & & 9 & 2.4 & 0.0003 \\
\hline translational elongation & 31 & 0.2 & & & & 8 & 2.2 & $1.5 \mathrm{E}-07$ \\
\hline $\begin{array}{l}\text { nitrogen compound } \\
\text { metabolism }\end{array}$ & 124 & 0.7 & & & & 8 & 2.2 & 0.004 \\
\hline amino acid biosynthesis & 99 & 0.5 & & & & 7 & 1.9 & 0.004 \\
\hline ribonucleotide biosynthesis & 45 & 0.2 & & & & 5 & 1.3 & 0.002 \\
\hline chlorophyll biosynthesis & 14 & 0.08 & & & & 4 & I.I & 0.0001 \\
\hline response to cytokinin stimulus & 31 & 0.2 & 3 & 5.6 & 0.0001 & 4 & 1.1 & 0.003 \\
\hline \multicolumn{9}{|l|}{ Down-regulated } \\
\hline response to abiotic stimulus & 1091 & 6.0 & & & & 40 & 15.5 & $3.2 \mathrm{E}-08$ \\
\hline secondary metabolism & 249 & 1.4 & & & & 14 & 5.4 & $1.4 \mathrm{E}-05$ \\
\hline $\begin{array}{c}\text { response to abscisic acid } \\
\text { stimulus }\end{array}$ & 113 & 0.6 & & & & 11 & 4.3 & $6.3 \mathrm{E}-07$ \\
\hline phenylpropanoid biosynthesis & 79 & 0.4 & & & & 7 & 2.7 & 0.0001 \\
\hline flavonoid biosynthesis & 30 & 0.2 & & & & 5 & 1.9 & $6.0 \mathrm{E}-05$ \\
\hline anthocyanin biosynthesis & 8 & 0.04 & I & 10 & 0.004 & 3 & 1.2 & 0.0002 \\
\hline starch biosynthesis & 7 & 0.04 & & & & 2 & 0.8 & 0.004 \\
\hline
\end{tabular}

The gene list was imported into GeneSpring. The number of genes in each biological process either in a whole genome (No. in Genome), or in the list (No. in list), as well as their corresponding percentage and p-value was generated by GeneSpring.

our study, probably due to the fact that their low $\mathrm{N}$ treatment was not severe enough to cause immediate $\mathrm{N}$ shortage as plant vacuoles have a storage capacity for nitrogen [24].

\section{Identification of putative nitrogen regulatory elements}

The promoters of co-expressed genes are likely to share common regulatory motifs and are potentially regulated by a common set of transcription factors. Therefore, identification of cis-regulatory elements in the promoter regions becomes an important first step in uncovering new facets of transcriptional regulation networks for $\mathrm{N}$ responses. Target genes were selected from the three main stages of $\mathrm{N}$ assimilation, namely nitrate uptake, nitrate reduction and ammonium assimilation. Included were one of the major nitrate transporters (NRT1.1), nitrate reductase and nitrite reductase (NR1, NR2 and NiR), glutamine synthetase (GS1-1 and GS1-4) and asparagine synthetase (AS2). Data from the five $\mathrm{N}$ conditions (15 microarray chips) were used for clustering genes with the expression pattern most similar to those of the selected target genes. The cluster 1 (22 genes) included the target gene NRT1.1, as well as other transporter genes such as CLC-b chloride channel protein (At3g27170), the glutamine transporter (At3g56200), the sulphate transporter protein (At1g23090), the carbohydrate transporter (At1g08930 and At4g17550), and the sodium-dicarboxylate cotransporter (At5g47560), implying the coordinated 
regulation of different aspects of metabolism. The genes in cluster 1 had higher baseline expression levels under $\mathrm{N}$ stress. They were up-regulated after $2 \mathrm{hr} \mathrm{N}$ induction followed by an expression decline after $24 \mathrm{hrs}$ (Figure 2). The cluster 2 (26 genes) included four target genes: NR1, NR2, $\mathrm{NiR}$ and $A S 2$, as well as genes involved in glucose metabolism (At1g24280) and trehalose metabolism (At5g51460). Since C and N metabolism are very closely linked, it is interesting to note that some key enzymes in $\mathrm{C}$ and $\mathrm{N}$ metabolism fall into the same cluster. The genes in cluster 2 had a lower baseline under $\mathrm{N}$ stress. They were all up-regulated after $2 \mathrm{hr} \mathrm{N}$ induction and then decreased after 24 hrs (Figure 2). The cluster 3 (60 genes) included the target gene GS1-1. Genes involved in anthocyanin synthesis (At4g22880), and the rate-limiting enzyme in flavonol and anthocyanin biosynthesis chalcone synthase (At5g13930) were also in this cluster. The cluster 4 (50 genes) included the target gene GS1-4, as well as genes involved in anthocyanin synthesis (At5g42800), and the key enzyme in phenylprepanoid biosynthesis phenylalanine ammonia lyase (At2g37040), suggesting a close linkage between these metabolic pathways. The pattern of cluster 3 and 4 was similar in that they had higher baseline expression under $\mathrm{N}$ stress and they were repressed after the $2 \mathrm{hr} \mathrm{N}$ induction and then further decreased after 24 hrs (Figure 2). The entire list of genes in the four clusters is provided in Additional file 7, together with their functional and pathway assignments.

The upstream regions $1 \mathrm{~kb}$ onward from the ATG start sites of the genes present in the four clusters were analyzed for cis elements. A motif-module discovery algorithm, CisModule [53], was used to detect motif patterns and the 5 most highly over-represented patterns were found (Table 6 ). Those candidate motifs were subsequently searched against the PLACE database [54] to identify those containing previously published plant cis elements in both forward and reverse strand. GATA motifs were found in cluster 1, 2 and 4, Dof motifs were found in all four clusters, Myb motifs found in cluster 1 and 2, and WRKY and CCAAT motifs found in cluster 4 (Table 6).

To compare the results obtained from CisModule, another algorithm BioProspector was used to look for regulatory sequence motifs [55]. The top 5 over-represented patterns found are listed in Table 6 . Various motif finding software programs typically yield candidate cis elements not entirely consistent with each other due to the differences in their underlying statistical algorithms. CisModule is based on a Bayesian hierarchical mixture model to infer motifs by their sequence background. BioProspector, on the other hand, uses a Gibbs sampling strategy to identify motifs. Less than five significant patterns were found for cluster 1, 3 and 4 by BioProspector, based on its significance level judged by its probability ( $\mathrm{p}$-value $<10^{-5}$ in this case). These candidate motifs were subsequently searched

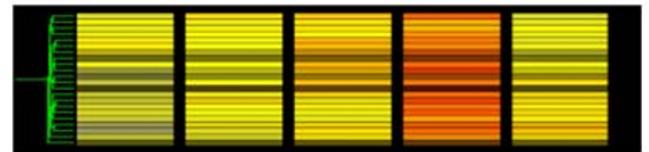

Cluster 1 (NRT1.1)

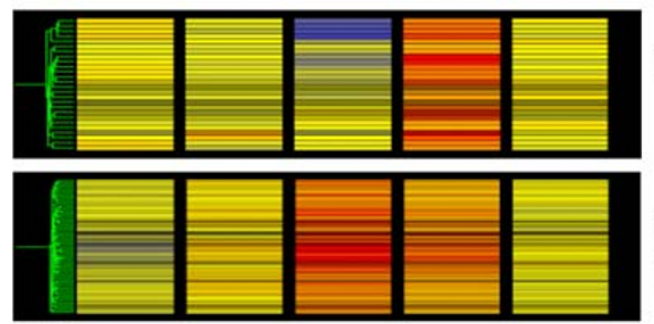

Cluster 2 (NiR)

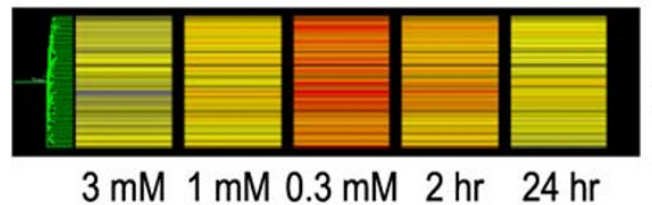

Cluster 3 (GS1-1)

\section{Figure 2}

Expression patterns of genes in each cluster. Relative expression levels of genes in each cluster were presented. The warmer the colors are, the higher the expression levels are. $3 \mathrm{mM}=$ the sufficient- $\mathrm{N}$ condition; I $\mathrm{mM}=$ the limiting$\mathrm{N}$ condition; $0.3 \mathrm{mM}=$ the stress $-\mathrm{N}$ condition; $2 \mathrm{hr}=2 \mathrm{hr}$ induction; $24 \mathrm{hr}=24 \mathrm{hr}$ induction. Each line represents one gene and the gene list is provided in Additional file 7.

against the PLACE database [54]. Again, GATA motifs were found in both cluster 2 and 4, Dof motifs in clusters 1 and 2, and Myb in cluster 2 (Table 6).

GATA motifs have been identified in the regulatory regions of many genes involved in nitrate assimilation such as nitrate reductase, nitrite reductase and glutamine synthetase $[29,56,57]$. Previously we identified regions of the spinach nitrite reductase $(\mathrm{NiR})$ promoter that are involved in $\mathrm{N}$ regulation $[28,29,58]$. Footprinting assay suggests that GATA factors play a role in NiR gene regulation [29]. Therefore, the presence of GATA enriched motifs discovered by both algorithms in a NiR gene cluster lends substantial support to the validity of these putative motifs. Interestingly, the GATA motif was found in the NiR cluster as well as in the GS1-4 cluster by both algorithms. However, the expression patterns of these two clusters are very different, suggesting there are positive and negative GATA regulators. Also, the GATA motif was found by both algorithms only in the GS1-4 cluster, but not in the GS1-1 cluster, although the expression patterns of these two clusters are very similar, suggesting a complex regulatory system. Arabidopsis has 30 GATA transcription factor genes $[39,59]$, but only a few of them have been functionally characterized [60-63], and none has been shown to be directly involved in $\mathrm{N}$ regulation. 
Table 6: Motifs identified by CisModule and BioProspector

\begin{tabular}{|c|c|c|c|}
\hline cluster & motifs & $\begin{array}{l}\text { Known TF binding sequence } \\
\text { contained (Reverse) }\end{array}$ & Binding (Reverse) \\
\hline \multicolumn{4}{|l|}{ CisModule } \\
\hline \multirow[t]{5}{*}{ Cluster I (NRTI.I) } & ARARRARRAG & AAAG & Dof \\
\hline & CWMGTGKSSC & & \\
\hline & YAWAWAWMWAWAA & TAACAAA (GATA) & Myb (GATA) \\
\hline & SRSCCACCAC & & \\
\hline & ARAGRARRAG & AAAG & Dof \\
\hline \multirow[t]{5}{*}{ Cluster 2 (NiR) } & MAMAAAHAWAWA & & \\
\hline & CAYATCYMYCWC & (GATA, GGATA) & (GATA, Myb) \\
\hline & GRRAGARRRRRR & AAAG & Dof \\
\hline & ASAWRTATATR & & \\
\hline & RRAGARRARRRG & AAAG & Dof \\
\hline \multirow[t]{5}{*}{ Cluster 3 (GSI-I) } & AMMAAAMAAAAAAA & & \\
\hline & RRARRARRAGA & AAAG & Dof \\
\hline & YGRHSACGTSR & & \\
\hline & WDMTATATRWW & & \\
\hline & YGGHSACGTSR & & \\
\hline \multirow[t]{5}{*}{ Cluster 4 (GSI-4) } & TWKGTTTKGKT & & \\
\hline & CGTGRYYGSTVS & TGAC (CCAAT) & WRKY (CCAAT) \\
\hline & KATATAKAKAT & GATA & GATA \\
\hline & AGAARAMRAAR & AAAG & Dof \\
\hline & GRSMCRYGWSR & & \\
\hline \multicolumn{4}{|l|}{ BioProspector } \\
\hline Cluster I (NRTI.I) & MAAMARAMAAAAAAAA & AAAG & Dof \\
\hline \multirow[t]{6}{*}{ Cluster 2 (NiR) } & MWTRGMCAWTCMTWWY & CCAAT & CCAAT \\
\hline & RATAKGAATGTCYAWK & CCAAT & \\
\hline & RAWTTGRTMGGAWTK & GATA (CCAAT) & GATA (CCAAT) \\
\hline & TKTTTYTYTTTTTTTT & $(\mathrm{AAAG})$ & (Dof) \\
\hline & WTRGAYATTCMTATY & GATA & GATA \\
\hline & & GGATA & Myb \\
\hline \multirow[t]{2}{*}{ Cluster 3 (GSI-I) } & GGWSACGTGGMRA & & \\
\hline & AARWAAAAAAAWAAAA & & \\
\hline \multirow[t]{2}{*}{ Cluster 4 (GSI-4) } & WWWTWTTRTTTTMTT & & \\
\hline & GARACAGASAGWKWSA & GATA (TAACTG) & GATA (Myb) \\
\hline
\end{tabular}

Candidate motifs from each cluster were identified by CisModule or BioProspector. They were subsequently searched against PLACE database to identify those containing previously published plant cis elements in the forward and reverse strand. Nucleotide abbreviations: $R: A$ or $G ; Y: C$ or $T$; W: A or T; S: G or C; M: A or C; K: G or T; H: A, C or T; B: G, C or T; V: G, A or C; D: G, A or T; N: G, A, C or T.

The Dof transcription factors belong to the same $\mathrm{C}_{2} \mathrm{C}_{2}$ zinc finger transcription factor family as the GATA factors $[64,65]$. They are associated with expression of multiple genes involved in carbon metabolism in maize [66], but not in nitrogen metabolism. Dof factors were identified in all four clusters by CisModule and in two clusters by BioProspector. It is tempting to speculate that Dof factors could play an important role in nitrogen regulation. This speculation is supported by the fact that improved nitrogen assimilation and growth under low-nitrogen conditions could be achieved in Dof1 over-expressed plants [67].

In addition to the Dof factors, binding sequences for other factors such as CCAAT, Myb and WRKY were found in these clusters either by one of the algorithms or by both. Members of the CCAAT, Myb and WRKY factors have been shown to be involved in various abiotic stress regulation/ tolerance $[46,49-51,68]$. Whether some of them are more specifically involved in $\mathrm{N}$ regulation requires further investigation. The putative regulatory elements identified in these clusters along with several other known motifs involved in $\mathrm{N}$ and $\mathrm{C}$ metabolism as well as stress response revealed a complex picture of plant $\mathrm{N}$ regulation.

\section{Conclusion}

We used an Arabidopsis whole genome array for a global evaluation of gene expression under different $\mathrm{N}$ conditions. The differentially expressed genes identified provide additional insights into the coordination of the complex 
$\mathrm{N}$ responses of plants and the components of the $\mathrm{N}$ response mechanism. Putative $\mathrm{N}$ regulatory elements were identified along with several previously known motifs involved in N, C, and stress responses. A better understanding of the complex regulatory network for plant $\mathrm{N}$ responses will ultimately lead to strategies to improve $\mathrm{N}$ use efficiency in crop plants. Much remains to be done in order to fully construct the regulatory networks underlying this critical aspect of plant biology.

\section{Methods}

\section{Microarray data availability}

All expression data were collected in compliance with the MIAME standards [see Additional file 8] and are available through NASCArrays database with reference number NASCARRAYS-408.

\section{Plant growth conditions}

Wild type Arabidopsis thaliana (Columbia ecotype) plants were grown under hydroponic conditions. Plant seeds were sown in rockwool cubes $(25 \times 25 \times 40 \mathrm{~mm}$; Fibrex Insulations Inc, ON, Canada), which were equilibrated with a balanced nutrient solution containing $10 \mathrm{mM}$ $\mathrm{KH}_{2} \mathrm{PO}_{4}, 2 \mathrm{mM} \mathrm{MgSO}{ }_{4}, 1 \mathrm{mM} \mathrm{CaCl}, 0.1 \mathrm{mM}$ Fe-EDTA, $50 \mu \mathrm{M} \mathrm{H}_{3} \mathrm{BO}_{4}, 12 \mu \mathrm{M} \mathrm{MnSO}_{4^{\prime}} 1 \mu \mathrm{M} \mathrm{ZnCl}_{2}, 1 \mu \mathrm{M} \mathrm{CuSO}_{4^{\prime}}$ $0.2 \mu \mathrm{M} \mathrm{Na}_{2} \mathrm{MoO}_{4}$ and varying levels of nitrate. Around 200 rockwool cubes were then placed in a tray which was connected to an 18-liter nutrient solution reservoir for sub-irrigation. Nutrient solution was pumped once a day to the tray from the reservoir to wet the rockwool completely and flowed back to the reservoir by an adjustable pump (Aquarium systems, OH, USA). Each of the above described hydroponic systems was one experimental unit used for the different nitrate levels. The electrical conductivity (EC) and $\mathrm{pH}$ levels of the nutrient solutions in the reservoir were monitored by TDSTestr 10 (OAKTON Instruments, IL, USA) and pH Pro Meter (Spectrum Technologies Inc. IL, USA) and adjusted to their target levels twice a week. There were three nitrate levels (treatments) in the experiment with the $3 \mathrm{mM}$ nitrate as sufficient, 1 $\mathrm{mM}$ nitrate as the mild $\mathrm{N}$-limiting condition and $0.3 \mathrm{mM}$ nitrate as the severe $\mathrm{N}$-limiting condition. The targeted EC was 670,770 , and $840 \mathrm{ppm}$ respectively, and $\mathrm{pH}$ was around 6.0. Nitrate levels of the nutrient solutions in the reservoir were monitored by Cardy $\mathrm{NO}_{3}$ Nitrate Meter (Spectrum Technologies Inc. IL, USA). For the $\mathrm{N}$ induction, rockwool cubes with plants grown under $0.3 \mathrm{mM} \mathrm{N}$ were transferred to the tray with a connection to the $3 \mathrm{mM}$ $\mathrm{N}$ reservoir. Nutrient solution was then pumped to the tray from each unit at $11 \mathrm{AM}$ and shoots were harvested at 1 PM. The method to detect nitrate levels in the plants was described in Peng et al [69]. Plants were grown in a growth room with $16 \mathrm{hr}$ lighting per day under fluorescent lamps (with a photosynthetically active radiation of $150 \mu \mathrm{molm}^{-}$ ${ }^{2} \mathrm{~s}^{-1}$ ) at $23^{\circ} \mathrm{C}$ and $8 \mathrm{hr}$ dark at $18^{\circ} \mathrm{C}$ for three weeks before shoots were harvested. Shoot biomass was taken from an average of 6 to 8 plants and nitrate concentration from an average of 3 samples (each sample from a pool of 3 plants). In order to harvest sufficient material for RNA extraction, the number of plants pooled to run the microarray experiment was different. It was approximately 8 , 10 , and 16 plants respectively for the $\mathrm{N}$-sufficient, mild $\mathrm{N}$ stress and severe $\mathrm{N}$-stress conditions. Plants used for RNA extraction were different from those for fresh weight and nitrate concentration, but they were grown under same conditions.

\section{Microarray hybridization}

Five $\mu \mathrm{g}$ of total RNA from each sample was used to synthesize double-stranded cDNAs. Labeled complementary RNA, synthesized from the cDNA was hybridized to a custom designed Arabidopsis whole genome exon GeneChip array (SYNG002) as previously described [70]. The hybridization signals of the arrays were acquired by the GeneChip scanner 3000 and quantified by MAS 5.0 (Affymetrix). Each probe set measurement was summarized as a value of weighted average of all probes in a set, subtracting bottom $5 \%$ of average intensity of the entire array using a custom algorithm. The overall intensities of all probe sets of each array were further scaled to a target intensity of 100 to enable direct comparison.

\section{Microarray data analysis}

Out of a total of $26412 \times 15=396180$ data points in the five treatment groups, the custom algorithm flagged 20149 or $5 \%$ as 'Absent' (A), 153373 or $39 \%$ as 'Marginal' (M), and 222658 or $56 \%$ as 'Present' (P). Stepwise gene filtering was conducted in GeneSpring (Agilent, CA, USA). First, for each of the five treatment groups, each gene must have either a ' $\mathrm{P}$ ' or ' $\mathrm{M}$ ' flag in all 3 replicate samples. This was followed by a filtering second step requiring that at least one of the three samples had a 'P' flag. This essentially guaranteed that every gene remaining in a group would be 'PMM', 'PPM', or 'PPP' among the three replicates. For pairwise group comparisons determining differentially expressed genes, genes common to both groups were identified and data exported, $\log _{2}$ transformed, and analyzed in Statistical Analysis of Microarray (SAM) as two class unpaired t-test and at a permutation number of 500 [35].

\section{Clustering analysis}

For clustering analysis, those genes present in at least 2 out of the 5 treatment groups, totaling 17138, were exported into Gene Cluster 3.0 with the following clustering parameters selected: $\log 2$ transformation, Hierachical clustering, Correlation (centered), and Average linkage. 


\section{Arabidopsis motif analyses}

Gene clusters containing several target genes were identified with correlation coefficients within a cluster greater than 0.9 . The corresponding $1 \mathrm{~kb}$ upstream sequences for each gene were downloaded from The Arabidopsis Information Resource [39] as of June 14, 2006 and used as input files for motif search in BioProspector [55] and CisModule [53]. For BioProspector, the entire $1 \mathrm{~kb}$ upstream sequence of Arabidopsis genome was used as the background distribution. The other parameters were set as follows: motif width, 6 to 16 bps; number of Monte Carlo simulations, 100; number of times to search for motifs, 100; number of top motifs to report, 10. For CisModule, all upstream sequences were masked by Repeatmasker [71] prior to motif analysis. The program settings were: number of motifs, 3 or 5; degenerate to independent motif sampler; total number of iterations, 1000; search both strands; and run dataset 10 times. Motif outputs from both BioProspector and CisModule were subsequently searched against PLACE database [54] as of August 31, 2006 to identify those containing previously published plant cis-elements.

\section{Authors' contributions}

YMB designed and conducted the experiment, analyzed data and drafted the manuscript. RLW performed data analysis, searched putative regulatory elements and provided critical revisions to the manuscript. $\mathrm{TZ}$ coordinated the microarray experiments and provided insights on the motif search. SJR designed and coordinated the experiment and finalized the manuscript. All authors read and approved the final manuscript.

\section{Additional material}

\section{Additional file 1}

Validation of microarray results by semi-quantitative RT-PCR. Click here for file

[http://www.biomedcentral.com/content/supplementary/1471-

2164-8-281-S1.pdf]

\section{Additional file 2}

The significant gene list under mild $N$ stress.

Click here for file

[http://www.biomedcentral.com/content/supplementary/1471-

2164-8-281-S2.xls]

\section{Additional file 3}

The significant gene list under severe $N$ stress.

Click here for file

[http://www.biomedcentral.com/content/supplementary/1471-

2164-8-281-S3.xls]

\section{Additional file 4}

The overlapping gene list between mild and severe $N$ stress. Click here for file

[http://www.biomedcentral.com/content/supplementary/14712164-8-281-S4.xls]

\section{Additional file 5}

The significant gene list after short-term $\mathrm{N}$ increase. Click here for file

[http://www.biomedcentral.com/content/supplementary/14712164-8-281-S5.xls]

\section{Additional file 6}

The significant gene list after long-term $N$ increase. Click here for file

[http://www.biomedcentral.com/content/supplementary/14712164-8-281-S6.xls]

\section{Additional file 7}

The gene list in each cluster.

Click here for file

[http://www.biomedcentral.com/content/supplementary/1471-

2164-8-281-S7.xls]

\section{Additional file 8}

MIAME checklist.

Click here for file

[http://www.biomedcentral.com/content/supplementary/1471-

2164-8-281-S8.doc]

\section{Acknowledgements}

We acknowledge M. Ono and C. Chilcott (Syngenta) for conducting microarray experiments; Dr. J. Colasanti (University of Guelph) for critical reading of the manuscript; Dr. Y. Zheng (University of Guelph) for advice on hydroponic system; J. Zhang (University of Guelph) for help with GeneSpring; T. Signorelli and R. Zhao (University of Guelph) for help growing plants. This work was supported by the Natural Sciences and Engineering Research Council of Canada and Syngenta Biotechnology Inc. to S.J.R. It has been reviewed by the US EPA and approved for publication.

\section{References}

I. Lea PJ, Morot-Gaudry JF: Plant nitrogen. Berlin ; London, Springer; 200I:xi, 407 p..

2. Scheible WR, Lauerer M, Schulze ED, Caboche M, Stitt M: Accumulation of nitrate in the shoot acts as a signal to regulate shoot-root allocation in tobacco. Plant Journal 1997, I I(4):67I-69I.

3. Zhang HM, Forde BG: An Arabidopsis MADS box gene that controls nutrient-induced changes in root architecture. Science 1998, 279(5349):407-409.

4. Stitt M, Krapp A: The interaction between elevated carbon dioxide and nitrogen nutrition: the physiological and molecular background. Plant Cell and Environment 1999, 22(6):583-62I.

5. Marschner H: Mineral nutrition of higher plants. 2nd ed. edition. London , Academic; 1995:xv,889p..

6. Good AG, Shrawat AK, Muench DG: Can less yield more? Is reducing nutrient input into the environment compatible with maintaining crop production? Trends Plant Sci 2004, 9(12):597-605.

7. Nosengo N: Fertilized to death. Nature 2003, 425(696I):894-895.

8. Giles J: Nitrogen study fertilizes fears of pollution. Nature 2005 , 433(7028):79|-79I. 
9. Crawford NM, Forde BG: Molecular and Developmental Biology of Inorganic Nitrogen Nutrition. In The Arabidopsis Book Edited by: Meyerowitz EM. Rockville, MD , American Society of Plant Biologists; 2002.

10. Crawford NM, Glass ADM: Molecular and physiological aspects of nitrate uptake in plants. Trends in Plant Science 1998 , 3(10):389-395.

II. Crawford NM: Nitrate - Nutrient and Signal for Plant-Growth. Plant Cell 1995, 7(7):859-868.

12. Stitt M: Nitrate regulation of metabolism and growth. Current Opinion in Plant Biology 1999, 2(3): 178-186.

13. Lam HM, Coschigano KT, Oliveira IC, Melo-Oliveira R, Coruzzi GM: The Molecular-Genetics of Nitrogen Assimilation into Amino Acids in Higher Plants. Annu Rev Plant Physiol Plant Mol Biol 1996, 47:569-593.

14. Campbell WH: NITRATE REDUCTASE STRUCTURE, FUNCTION AND REGULATION: Bridging the Gap between Biochemistry and Physiology. Annu Rev Plant Physiol Plant Mol Biol 1999, 50:277-303.

15. Cheng CL, Dewdney J, Kleinhofs A, Goodman HM: Cloning and nitrate induction of nitrate reductase mRNA. Proc Natl Acad Sci U S A 1 986, 83( (18):6825-6828.

16. Crawford NM, Campbell WH, Davis RW: Nitrate reductase from squash: cDNA cloning and nitrate regulation. Proc Natl Acad Sci US A 1986, 83(2I):8073-8076.

17. Scheible WR, GonzalezFontes A, Lauerer M, MullerRober B, Caboche $M$, Stitt $M$ : Nitrate acts as a signal to induce organic acid metabolism and repress starch metabolism in tobacco. Plant Cell 1997, 9(5):783-798.

18. Wang R, Guegler K, LaBrie ST, Crawford NM: Genomic analysis of a nutrient response in Arabidopsis reveals diverse expression patterns and novel metabolic and potential regulatory genes induced by nitrate. Plant Cell 2000, 12(8): 149|-I509.

19. Wang RC, Okamoto M, Xing XJ, Crawford NM: Microarray analysis of the nitrate response in Arabidopsis roots and shoots reveals over 1,000 rapidly responding genes and new linkages to glucose, trehalose-6-phosphate, iron, and sulfate metabolism. Plant Physiology 2003, I 32(2):556-567.

20. Scheible WR, Morcuende R, Czechowski T, Fritz C, Osuna D, Palacios-Rojas N, Schindelasch D, Thimm O, Udvardi MK, Stitt M Genome-wide reprogramming of primary and secondary metabolism, protein synthesis, cellular growth processes, and the regulatory infrastructure of Arabidopsis in response to nitrogen. Plant Physiology 2004, I 36(I):2483-2499.

21. Coruzzi G, Bush DR: Nitrogen and carbon nutrient and metabolite signaling in plants. Plant Physiol 200I, I 25(I):6I-64.

22. Coruzzi GM, Zhou L: Carbon and nitrogen sensing and signaling in plants: emerging 'matrix effects'. Curr Opin Plant Biol 200 I, 4(3):247-253.

23. Price J, Laxmi A, St Martin SK, Jang JC: Global transcription profiling reveals multiple sugar signal transduction mechanisms in Arabidopsis. Plant Cell 2004, 16(8):2 I28-2I 50.

24. Lian X, Wang S, Zhang J, Feng Q, Zhang L, Fan D, Li X, Yuan D, Han $B$, Zhang Q: Expression profiles of 10,422 genes at early stage of low nitrogen stress in rice assayed using a cDNA microarray. Plant Mol Biol 2006, 60(5):6I7-63I.

25. Lin $Y$, Hwang CF, Brown JB, Cheng CL: 5 ' proximal regions of Arabidopsis nitrate reductase genes direct nitrate-induced transcription in transgenic tobacco. Plant Physiol 1994, 106(2):477-484.

26. Neininger A, Back E, Bichler J, Schneiderbauer A, Mohr H: Deletion Analysis of a Nitrite-Reductase Promoter from Spinach in Transgenic Tobacco. Planta 1994, 194(2): 186-192.

27. Dorbe MF, Truong HN, Crete P, Daniel-Vedele F: Deletion analysis of the tobacco Niil promoter in Arabidopsis thaliana. Plant Science 1998, 139(1):71-82.

28. Back E, Dunne W, Schneiderbauer A, de Framond A, Rastogi R, Rothstein S): Isolation of the spinach nitrite reductase gene promoter which confers nitrate inducibility on GUS gene expression in transgenic tobacco. Plant Mol Biol 1991, I7(I):9-18.

29. Rastogi R, Bate NJ, Sivasankar S, Rothstein SJ: Footprinting of the spinach nitrite reductase gene promoter reveals the preservation of nitrate regulatory elements between fungi and higher plants. Plant Mol Biol I997, 34(3):465-476.
30. Palenchar PM, Kouranov A, Lejay LV, Coruzzi GM: Genome-wide patterns of carbon and nitrogen regulation of gene expression validate the combined carbon and nitrogen $(\mathrm{CN})$-signaling hypothesis in plants. Genome Biol 2004, 5(I I):R9I.

31. Naito S, Hirai MY, Chino M, Komeda Y: Expression of a Soybean (Glycine max [L.] Merr.) Seed Storage Protein Gene in Transgenic Arabidopsis thaliana and Its Response to Nutritional Stress and to Abscisic Acid Mutations. Plant Physiol 1994, 104(2):497-503.

32. Robinson D: What limits nitrate uptake from soil? Plant Cell Environ 1991, 14:77-85

33. Scheible WR, Krapp A, Stitt M: Reciprocal diurnal changes of phosphoenolpyruvate carboxylase expression and cytosolic pyruvate kinase, citrate synthase and NADP-isocitrate dehydrogenase expression regulate organic acid metabolism during nitrate assimilation in tobacco leaves. Plant Cell and Environment 2000, 23(II): II55-II67.

34. Zhu T: Global analysis of gene expression using GeneChip microarrays. Current Opinion in Plant Biology 2003, 6(5):4I8-425.

35. Tusher VG, Tibshirani R, Chu G: Significance analysis of microarrays applied to the ionizing radiation response. Proc Natl Acad Sci U S A 200I, 98(9):5II6-5I 21 .

36. Misson J, Raghothama KG, Jain A, Jouhet J, Block MA, Bligny R, Ortet P, Creff A, Somerville S, Rolland N, Doumas P, Nacry P, HerrerraEstrella L, Nussaume L, Thibaud MC: A genome-wide transcriptional analysis using Arabidopsis thaliana Affymetrix gene chips determined plant responses to phosphate deprivation. Proc Natl Acad Sci U S A 2005, 102(33): I I 934-I 1939.

37. Gene Ontology database [http://geneontology.org]

38. Kyoto Encyclopedia of Genes and Genomes www.genome.ad.jp/kegg]

39. Arabidopsis Information Resource website bidopsis.org/tools/bulk/go/index.jsp]

40. Provart NJ, Gil P, Chen W, Han B, Chang HS, Wang X, Zhu T: Gene expression phenotypes of Arabidopsis associated with sensitivity to low temperatures. Plant Physiol 2003, I32(2):893-906.

4l. Coruzzi G: Primary N-assimilation into amino acids in Arabidopsis. In The Arabidopsis book Edited by: Meyerowitz EM. Rockville, MD , American Society of Plant Biologists; 2003.

42. De Angeli A, Monachello D, Ephritikhine G, Frachisse JM, Thomine S Gambale F, Barbier-Brygoo H: The nitrate/proton antiporter AtCLCa mediates nitrate accumulation in plant vacuoles. Nature 2006, 442(7 I 05):939-942.

43. Diaz U, Saliba-Colombani V, Loudet O, Belluomo P, Moreau L, Daniel-Vedele F, Morot-Gaudry JF, Maselaux-Daubresse U: Leaf yellowing and anthocyanin accumulation are two genetically independent strategies in response to nitrogen limitation in Arabidopsis thaliana. Plant and Cell Physiology 2006, 47(I):74-83.

44. Dixon RA, Paiva NL: Stress-Induced Phenylpropanoid Metabolism. Plant Cell 1995, 7(7): 1085-1097.

45. Borevitz JO, Xia YJ, Blount J, Dixon RA, Lamb C: Activation tagging identifies a conserved MYB regulator of phenylpropanoid biosynthesis. Plant Cell 2000, I 2( I 2):2383-2393

46. Eulgem T, Rushton PJ, Robatzek S, Somssich IE: The WRKY superfamily of plant transcription factors. Trends in Plant Science 2000 , 5(5): 199-206.

47. Nakano T, Suzuki K, Ohtsuki N, Tsujimoto Y, Fujimura T, Shinshi H: Identification of genes of the plant-specific transcription-factor families cooperatively regulated by ethylene and jasmonate in Arabidopsis thaliana. Journal of Plant Research 2006, I I 9(4):407-4I3.

48. Fujimoto SY, Ohta M, Usui A, Shinshi H, Ohme-Takagi M: Arabidopsis ethylene-responsive element binding factors act as transcriptional activators or repressors of GCC box-mediated gene expression. Plant Cell 2000, I 2(3):393-404.

49. Chinnusamy V, Schumaker K, Zhu JK: Molecular genetic perspectives on cross-talk and specificity in abiotic stress signalling in plants. Journal of Experimental Botany 2004, 55(395):225-236.

50. Alonso-Blanco C, Gomez-Mena C, Llorente F, Koornneef M, Salinas J, Martinez-Zapater JM: Genetic and molecular analyses of natural variation indicate CBF2 as a candidate gene for underlying a freezing tolerance quantitative trait locus in Arabidopsis. Plant Physiology 2005, 139(3): |304-|3|2.

5I. Lee BH, Henderson DA, Zhu JK: The Arabidopsis cold-responsive transcriptome and its regulation by ICE I. Plant Cell 2005 , I7(II):3155-3175. 
52. Lejay L, Tillard P, Lepetit M, Olive F, Filleur S, Daniel-Vedele F, Gojon $A$ : Molecular and functional regulation of two NO3- uptake systems by $\mathbf{N}$ - and $\mathbf{C}$-status of Arabidopsis plants. Plant $\mathrm{J} 1999$, I 8(5):509-5I9.

53. Zhou Q, Wong WH: CisModule: de novo discovery of cis-regulatory modules by hierarchical mixture modeling. Proc Natl Acad Sci U S A 2004, I 0 I(33): I I I |4- I 2 I I 9

54. Higo K, Ugawa $Y$, Iwamoto $M$, Korenaga T: Plant cis-acting regulatory DNA elements (PLACE) database: 1999. Nucleic Acids Res 1999, 27(I):297-300.

55. Liu X, Brutlag DL, Liu JS: BioProspector: discovering conserved DNA motifs in upstream regulatory regions of co-expressed genes. Pac Symp Biocomput 200I:127-138.

56. Jarai G, Truong HN, Daniel-Vedele F, Marzluf GA: NIT2, the nitrogen regulatory protein of Neurospora crassa, binds upstream of nia, the tomato nitrate reductase gene, in vitro. Curr Genet 1992, 2 I(I):37-4I

57. Oliveira IC, Coruzzi GM: Carbon and amino acids reciprocally modulate the expression of glutamine synthetase in Arabidopsis. Plant Physiol 1999, I2I(1):301-310.

58. Rastogi R, Dulson J, Rothstein S): Cloning of tomato (Lycopersicon esculentum Mill.) arginine decarboxylase gene and its expression during fruit ripening. Plant Physiol 1993 I 03(3):829-834

59. Reyes JC, Muro-Pastor MI, Florencio FJ: The GATA family of transcription factors in Arabidopsis and rice. Plant Physiol 2004, 134(4): $1718-1732$.

60. Nishii A, Takemura M, Fujita H, Shikata M, Yokota A, Kohchi T: Characterization of a novel gene encoding a putative single zinc-finger protein, ZIM, expressed during the reproductive phase in Arabidopsis thaliana. Biosci Biotechnol Biochem 2000 64(7): 1402-1409.

61. Zhao Y, Medrano L, Ohashi K, Fletcher JC, Yu H, Sakai H, Meyerowitz EM: HANABA TARANU is a GATA transcription factor that regulates shoot apical meristem and flower development in Arabidopsis. Plant Cell 2004, I6( I 0):2586-2600.

62. Bi YM, Zhang Y, Signorelli T, Zhao R, Zhu T, Rothstein S: Genetic analysis of Arabidopsis GATA transcription factor gene family reveals a nitrate-inducible member important for chlorophyll synthesis and glucose sensitivity. Plant Journal 2005, 44(4):680-692.

63. Liu PP, Koizuka N, Martin RC, Nonogaki H: The BME3 (Blue Micropylar End 3) GATA zinc finger transcription factor is a positive regulator of Arabidopsis seed germination. Plant $J$ 2005, 44(6):960-971.

64. Riechmann JL, Heard J, Martin G, Reuber L, Jiang C, Keddie J, Adam L, Pineda O, Ratcliffe OJ, Samaha RR, Creelman R, Pilgrim M, Broun P, Zhang JZ, Ghandehari D, Sherman BK, Yu G: Arabidopsis transcription factors: genome-wide comparative analysis among eukaryotes. Science 2000, 290(5499):2 105-2 110.

65. Yanagisawa S: The Dof family of plant transcription factors. Trends Plant Sci 2002, 7( I 2):555-560.

66. Yanagisawa S: DofI and Dof2 transcription factors are associated with expression of multiple genes involved in carbon metabolism in maize. Plant $J 2000,21(3): 28 I-288$.

67. Yanagisawa S, Akiyama A, Kisaka H, Uchimiya H, Miwa T: Metabolic engineering with Dofl transcription factor in plants: Improved nitrogen assimilation and growth under low-nitrogen conditions. Proc Natl Acad Sci U S A 2004, I 0 I (20):7833-7838.

68. Chen YH, Yang XY, He K, Liu MH, Li JG, Gao ZF, Lin ZQ, Zhang YF, Wang $X X$, Qiu XM, Shen YP, Zhang L, Deng XH, Luo JC, Deng XW, Chen ZL, Gu HY, Qu LJ: The MYB transcription factor superfamily of arabidopsis: Expression analysis and phylogenetic comparison with the rice MYB family. Plant Molecular Biology 2006, 60(I):107-124.

69. Peng M, Hannam C, Gu H, Bi YM, Rothstein SJ: A mutation in NLA, which encodes a RING-type ubiquitin ligase, disrupts the adaptability of Arabidopsis to nitrogen limitation. Plant J 2007, 50(2):320-337.

70. Zhu T, Budworth P, Han B, Brown D, Chang HS, Zou GZ, Wang X: Toward elucidating the global gene expression patterns of developing Arabidopsis: Parallel analysis of 8300 genes by a high-density oligonucleotide probe array. Plant Physiology and Biochemistry 200I, 39(3-4):22I-242.

7I. Smit AFA, Hubley R, Green P: Repeatmasker Open-3.0. 1996 [http://www.repeatmasker.org].
Publish with Biomed Central and every scientist can read your work free of charge

"BioMed Central will be the most significant development for disseminating the results of biomedical research in our lifetime. "

Sir Paul Nurse, Cancer Research UK

Your research papers will be:

- available free of charge to the entire biomedical community

- peer reviewed and published immediately upon acceptance

- cited in PubMed and archived on PubMed Central

- yours - you keep the copyright

Submit your manuscript here:

http://www.biomedcentral.com/info/publishing_adv.asp
BioMedcentral 